\title{
한국의 ODA예산 운영에 관한 비판적 고찰과 개선방안 연구
}

\author{
강 주 홍 (국무조정실 개발협력기획과 과장)
}

\section{목 차}

I. 서론

II. 이론적 논의

III. 우리나라 ODA예산의 운영실태 분석

$\mathrm{IV}$. 개선방안

$\mathrm{V}$. 결론

\section{I . 서론}

우리나라의 ODA예산 규모는 국제적 위상 제고·경제력 증대 등에 따라 연평균 $20 \%$ 가까이 증가('07 '13)하는 등 급속하게 증대하고 있다. 또한 최근 금융위기·유럽 재정위기 등 세계적 으로 어려운 경제여건 하에서도 2012년 우리나라의 ODA예산 증가율은 전년대비 $17.1 \%$ 증가 하여 OECD DAC회원국내에서 1위를 (2013년도 총 예산 규모는 전년대비 1천800억원(약 9. $7 \%$ ) 증가한 2조411억 원으로, 이는 $\mathrm{GNI}$ (국민총소득) 대비 $0.16 \%$ 다.) 차지하기도 하였다. 아 울러 국제사회에 약속한 대로 2015년까지 ODA/GNI 0.25\%를 달성한다면 우리 ODA예산은 '13년 현재 약 2 조 411 억 원에서 4조원 이상까지로 크게 증가할 전망이다.

그러나 이러한 ODA예산 규모의 확대(more aid)가 원조효과성 제고(better aid)로 연결되기 위해서는 일반적인 정부예산보다 더 많은 주의와 노력을 기울여야 한다. 이는 ODA예산이 갖 는 특성, 즉 정부예산이 갖는 일반적 특성에다 ODA가 갖는 사업상의 특성이 추가되는 성격 
때문이다. 예산은 공유재의 성격을 가지고 있어 적절한 통제장치가 마련되지 못하면 '공유지 의 비극'이 발생할 수 있다. 특히나 ODA예산은 그 사업 범위·종류 등이 광범위하고 다양하여 성과 비교 측정이 어렵고 각 부처·기관이 국제협력·경제협력 등의 일환으로 분권적으로 추진하 는 특성이 강해 예산통제가 더 어렵기 때문에 공유지의 비극이 발생할 가능성이 더욱 크다. 또 한 ODA사업 지역이 주로 해외에 넓게 분포하고 ODA사업성과 도출에 다년도 소요, 수원국의 경제발전·복지향상 기여 측정 등에 있어 정성적 평가 위주, 한 수원국내 다수 공여국의 원조활 동 혼재 등의 특성으로 인해 정보의 비대칭이 발생하고 이에 따라 본인-대리인 문제가 발생할 가능성이 일반 정부예산보다 더욱 크다. 그뿐 아니라 일반적인 정부예산과 달리 비용부담자는 대한민국 국민임에 비해 편익수혜자는 수원국의 국민과 정부가 되기 때문에 자원낭비가 발생 할 가능성이 더욱 크다. 요컨대 이러한 ODA예산의 특성으로 인해 효율성, 효과성, 책임성 등 의 확보가 일반 정부예산보다 더 어려운 측면이 있다. 따라서 급속하게 증대하는 ODA예산 규 모에 걸맞게 원조효과성 제고(better aid)가 이루어지도록 하기 위해서는 ODA예산의 특성을 감안하여 그에 적합한 개선방안을 조속히 보완강화할 필요가 있다.

ODA예산의 효과적·효율적 운영을 위해서는 우선, '공유지의 비극' 극복을 위해 예산총액 설 정.단계별 원조목표 등 국가 차원의 통합적인 원조전략을 수립하고 이 전략 하에 유무상 원조 규모, 지역별·분야별 배분규모 등을 확정한 후 유무상 원조기관(EDCF, KOICA 등)의 유기적인 연계체계 구축을 통해 사업간 중복분절화를 예방해야 한다. 둘째, 정보의 비대칭에 따른 본인 -대리인 문제 극복을 위해 유무상 원조기관간 그리고 수원국과의 정보공유상호참여 등이 제 도적으로 뒷받침되어야 한다. 셋째, 비용부담자-의사결정자-편익수혜자간 불일치에 따른 자 원낭비 극복 등을 위해서는 통제수단으로서 $\mathrm{ODA}$ 사업 평가를 강화하고 그 결과가 사업수정에 실질적으로 반영될 수 있는 시스템 구축 등이 필요하다.

본 연구는 문헌분석, $\mathrm{KOICA}$ 와 $\mathrm{EDCF}$ 그리고 총리실 등 관련 부처의 자료 분석, 기타 인터 넷자료 분석 등을 통해 이루어졌다. 


\section{II. 이론적 논의}

\section{1. 공유지의 비극}

소비에 있어서의 경합성 여부와 배제가능성 여부를 기준으로 재화를 구분할 때 공유재는 공 공 낚시터처럼 낚시행위를 금지할 수 없지만 추가적으로 한 사람이 더 낚시를 하게 되면 다른 사람들이 잡을 수 있는 고기의 양은 줄어들 수 밖에 없게 되는, 즉 배제의 가능성은 존재하지 않지만 소비는 경합적인 성격을 갖는다. 대가를 지불하지 않은 사람을 배제할 수 없다는 사실 은 곧 사람들이 공유재를 사용하는 데 드는 비용이 '0'이라는 것을 의미하고, 사람들은 재화로 부터 얻게 되는 한계편익이 재화의 가격과 일치되는 점까지 소비행위를 계속하므로, 결국 자 원이 고갈될 때까지 사람들은 공유재를 사용하게 될 것이다. 이에 따라 공유재에 있어서는 개 인효용의 단기적인 극대화와 장기적인 극대화 간에 갈등이 발생하게 되는데, 이를 공유의 비 극 혹은 공유지의 비극(the tragedy of the commons)이라고 한다. (하연섭, 2008 ; Garrett Hardin, 1968) 정부예산은 이와 같은 공유재의 성격을 갖는다.

공유지의 비극의 핵심은 외부성(externality)이며 편익의 개별화(편익은 집중)와 비용의 사 회화(비용은 분산) 즉, 특정 목적 공공정책의 자금조달을 위해 일반 조세재원을 사용하는 데 비롯된다. 이러한 외부성을 내재화하기 위해서는 의사결정자에게 자신들이 행하는 결정의 전 체적인 모습을 보여주는 집권화된(centralized) 예산과정이 필요하다. (von Hagen, Jűrgen. 2007) 즉 예산편성 단계에서 중장기 재정전략과 지표(parameter)를 설정하고 예산심의 단계 에서 상위 전략하에 사업의 특수성은 고려하되 공통된 기준과 지출 우선순위 등을 적용할 필 요가 있다.

또한 인센티브 측면에서도 예산과정에서 공유지의 비극이 발생하게 된다. 정부기관들은 총 지출에 대한 책임을 지려고 하지 않고 자신의 이익에 따라서 예산을 획득하려고 하며, 그 결과 개별적 지출행위가 총체적으로는 부정적 결과를 초래하기도 한다. 기존의 예산논의에서는 예 산과정상의 적법 절차(due process)를 거치면 정부기관간의 경쟁을 통해 포괄적이고 공정한 총량적 결정이 이루어질 수 있다고 여겨졌지만 오늘날의 논의에서는 각 기관들의 자기 이익적 행동으로 인하여 전체예산의 자원배분 및 운영상 비효율성을 낳고 있다고 분석한다. 개별 정 부기관은 총량적 예산규율보다 자기 부처의 이익을 증대하기 위한 노력에 인센티브를 갖고 있 기 때문이다. Schick, Allen. 1998) 그러므로 개별 정부기관들이 전체 예산의 규모를 파악할 
수 있게 하고 이를 고려하게끔 인센티브를 제공하는 한편, 총괄기관의 거시적이고 종합적인 조정능력이 요구된다.

\section{2. 본인-대리인(principal-agent) 문제}

민주주의의 핵심적인 내용은 주인인 국민들이 대리인인 정치인, 관료, 공공기관 등 정책결 정자들에게 예산 사용처의 결정을 위임했다는 것이다. 따라서 민주주의에 있어서 핵심적인 개 념은 국민에 대한 책무성(accountability)인 것이다. 그러나 정치경제적 환경의 복잡성으로 말 미암아 정치인들이 예산의 용도를 어떻게 결정하는지 국민들이 세세하게 감독하기는 실질적으 로 불가능하다. 따라서 민주주의의 형식적인 원칙에도 불구하고 유권자의 선호와 실제 정책이 일치하지 않을 가능성은 상당히 크다고 할 수 있다. (하연섭, 2010) 이러한 본인-대리인 문제 는 정부부처와 국회간의 관계에서는 물론 정부기관 내에서도 발생한다. 전자의 경우 정부부처 가 국회보다 더 많은 정보를 비대칭적으로 갖고 있기 때문이며 후자의 경우에도 마찬가지이 다. $\mathrm{ODA}$ 와 관련해서는 예컨대 $\mathrm{ODA}$ 의 유상원조 주관기관인 기획재정부와 무상원조 주관기관 인 외교부가 $\mathrm{EDCF}$ (수출입은행), $\mathrm{KOICA}$ 에게 각각 $\mathrm{ODA}$ 사업 시행기능을 위임했을 때 본인-대 리인 문제가 발생한다. $\mathrm{EDCF} \cdot \mathrm{KOICA}$ 등 $\mathrm{ODA}$ 시행기관이 정부 부처보다 ODA프로그램이나 수원국의 현지상황 등에 대해 더 많은 정보를 알고 있기 때문에 정책결정자를 포획할 수 있다. 자신의 조직 확장과 예산 극대화 추구 등 조직 자체의 이익을 추구하면서 민간에 대한 권력행 사가 일어나기도 한다. 요컨대 본인-대리인 문제는 어떤 일을 하려는데 여건상 본인이 직접 일을 처리할 수 없어서 다른 사람에게 일 처리를 맡기는 상황에서 정보의 비대칭성 때문에 발 생한다. 정보를 많이 갖고 있는 대리인의 감추어진 특성 또는 감추어진 행동 때문에 본인이 대 리인을 제대로 통제할 수 없고, 대리인이 자신의 이익을 추구하기 위하여 본인(principal)의 이익에 해로운 행동을 할 가능성이 다분히 존재한다는 의미이다. (전상경, 2005)

이러한 본인-대리인 문제 해결을 위해서는 정보의 대칭성 확보 노력은 물론 적절한 인센티 브가 제공되어야 한다. 이 문제는 사실 대리인이 본인의 이익을 위해 최선의 노력을 기울일 유 인이 결여되어 있기 때문에 발생하는 것이므로 본인이 적절한 유인구조를 제공해야 대리인의 행동을 바람직한 방향으로 유도할 수 있다.

또한 대리인의 책무성을 강화하기 위해서는 예산제도의 완전성(comprehensiveness)과 투 명성(transparency)을 높여야 한다. 정부지출이 예산외로 숨겨지거나 민주적 통제범위에서 
벗어나 있게 된다면 유권자들은 정부의 재정성과에 대하여 책임을 묻기 어렵기 때문이다. 국 민들이 정부활동에 관해 신뢰할 만하고, 포괄적이며, 시의적절하고, 쉽게 이해할 수 있는 그리 고 국제적으로 비교가능한 정보를 쉽게 접할 수 있어야 예산투명성이 제고될 수 있다(하연섭, 2010) 이를 통하여 정부의 재정상황과 정부활동에 소요되는 비용과 정부활동으로부터의 편익 을 쉽게 알 수 있게 된다. 아울러 대리인 통제를 위해서는 대리인간 경쟁을 조성하여 대리인 자신의 이익추구 활동을 최소화하고 본인을 위한 성과창출에 더욱 집중토록 할 필요가 있다.

\section{3. 비용부담자, 의사결정자, 편익수혜자의 불일치}

민간예산이나 일상생활에서는 비용을 부담하는 주체와 의사결정자, 그리고 편익수혜자가 일치한다. 그러나 정부예산에서는 이 세 사람이 일치하지 않는 경우가 대부분이다. 즉 정부가 활동하는 데 필요한 비용을 부담하는 사람과 정부활동으로부터 혜택을 받는 사람이 일치하지 않는다. 이와 동시에 정부가 활동하는 데 필요한 비용을 부담하는 사람과 예산을 어디에 어떻 게 사용할 지를 결정하는 사람도 일치하지 않는다. 비용을 부담하는 사람은 납세자인데 예산 의 사용을 결정하는 사람은 공무원과 의원이기 때문이다. 따라서 비용을 부담하는 사람들이 원하는 방향으로 공무원과 의원들이 예산의 사용을 결정하도록 어떻게 유도할 것인가가 예산 과정에서 중요한 과제가 되는 것이다. 또한 비용부담자와 편익의 수혜자가 일치하지 않기 때 문에 자원의 낭비가 발생할 위험성이 큰 데, 이를 어떻게 방지할 것인가 역시 예산과정에서 해 결해야 할 문제이다. 다시 말해서 예산의 운용과 관련된 책무성(accountability)을 어떻게 확 보할 것인가가 매우 중요한 과제라는 것이다. (하연섭, 2010) ODA예산은 이러한 정부예산의 특징에서 더 나아가, 비용부담자는 일반적인 정부예산과 마찬가지로 납세자임에 비해 개발협 력정책이 외교정책의 일환이므로 대중적 투명성을 높이기에는 한계가 있어 의사결정과정에 대 중의 참여를 제한하기도 하고 $\mathrm{ODA}$ 예산이 전체 예산중 상당히 적은 부분을 차지할 뿐만 아니 라 실제 $\mathrm{ODA}$ 예산집행의 결과가 국민생활에 직접적인 영향을 미치지도 않아 납세자의 관심도 도 낮은 편이다. 특히 ODA예산의 편익수혜자는 개도국의 국민이나 정부로서 이들은 더 많은 원조를 받기 위해, 또 원조가 없는 것 보다는 일단 원조를 받는 것이 그들에게 혜택이 되기 때

문에 대부분 ODA예산 집행결과의 편익을 부풀리거나 평가에 관대하게 답변하는 경향이 있어 정확한 편익산정도 어렵다. 결국 정부예산과 마찬가지로 세 주체간의 불일치 문제가 있지만 $\mathrm{ODA}$ 예산은 불일치의 강도가 더 심하다고 할 수 있다. 따라서 책무성을 높이기 위해서는 사전 적인 통제와 함께 $\mathrm{ODA}$ 특성을 감안한 사후적인 평가가 강화될 필요가 있다. 


\section{III. 한국 ODA의 예산 현황 및 ODA 추진체계}

\section{1. 우리나라 ODA 예산 현황}

우리나라 ODA예산 규모는 국제적 위상 제고·경제력 증대 등에 따라 연평균 $20 \%$ 증가하고 있다. 특히 ' 12 년 우리나라 ODA 규모(순지출 기준)는 전년(13.2억불) 대비 $17.1 \%$ 증가한 15.5 억불로써 $\mathrm{DAC}$ 회원국(23개) 중 16 위를 차지하였고 $\mathrm{ODA}$ 예산 증가율로만 보면 $\mathrm{OECD} \mathrm{DAC}$ 회 원국내에서 1 위를 차지하였다. 최근 금융위기·유럽 재정위기 등 세계적으로 어려운 경제여건 하에서 우리나라를 포함하여 8개국을 제외한 대부분의 공여국들이 ODA예산규모를 줄인 데 비해 작년 우리나라의 ODA예산 증가율은 전년대비 $17.1 \%$ 증가하였다. (2013년도 총 예산 규 모는 전년대비 1 천 800 억원(약 9.7\%) 증가한 2조411억 원으로, 이는 $\mathrm{GNI}($ 국민총소득) 대비 $0.16 \%$ 다.) 그러나 12 년 $\mathrm{ODA} / \mathrm{GNI}$ 비율은 $0.14 \%$ 로 $\mathrm{OECD} \mathrm{DAC}$ 의 평균 $0.29 \%$ 에 미치지 못했 다. 올 해 총예산의 지역별 원조규모를 보면 아시아 지역이 6천16억원(42.2\%)으로 가장 많았 고 그다음은 아프리카 1 천589억원(11.1\%), 중남미 595억원(4.2\%), 중동 430 억원(3.0\%) 등의 순이다. 분야별로는 교통 2천555억원(17.9\%), 교육 1천871억원(13.1\%), 산업에너지 1천543 억원(10.8\%) 등으로 사회 - 경제 인프라 건설에 집중됐다. 정부는 또 몽골, 방글라데시, 우즈 베키스탄, 캄보디아, 필리핀 등 5 개국과 ODA 중점협략 분야 등을 포함하고 있는 국가협력전 략(CPS)을 확정했다. 이로써 26 개 중점협력대상국 중 14 개국에 대한 CPS 수립이 완료됐으며, 내년 상반기까지 나머지 12 개국에 대해서도 CPS 수립을 완료한다는 계획이다. 국제사회에 약 속한 대로 2015년까지 ODA/GNI 0.25\%를 달성한다면 우리 ODA예산은 '13년 현재 약 2조411 억 원 규모에서 4조원 이상까지로 크게 증가할 전망이다.

한편 '02 '11년의 지난 10년간 $\mathrm{ODA}$ 누계 중 지역별 평균 $\mathrm{ODA}$ 를 살펴보면, 아시아가 평균 $54 \%$ 의 지원을 받아 가장 주요한 지원 대상 지역이라 할 수 있다. 그 다음으로 아프리카 $(14 \%)$, 중동 $(11 \%)$ 순으로 지원되었다. 다만 2000 년대 초반에는 아시아 지역에 $70 \%$ 이상이 집중되었 던 반면, 2000 년대 중반 이후에는 아프리카에 대한 지원이 점차 증가하는 추세에 있다. ODA 의 분야별 지원은 교육·보건·수자원 및 위생·공공행정 등 사회인프라 및 서비스, 교통 및 물류· 통신·에너지·금융 등 경제인프라 및 서비스, 농림수산·산업 등 생산(산업)부문, 다부문 등으로 구분되는데, 지난 10년간 분야별 실적을 살펴보면 사회인프라 및 서비스 부문에 $46 \%$, 경제인 프라 및 서비스 부문에 $37 \%$ 로 집중되어 있음을 볼 수 있다. OECD DAC 회원국과 비교하면 2011년 유상비율은 우리나라가 총지출 기준 $44.4 \%$ 로서 DAC 회원국 평균 $15.0 \%$ 에 비해 높은 
편이며 DAC 회원국 중에는 포르투갈, 일본에 이어 3 위이다. DAC 회원국 중 유상을 실시하는 나라는 총 17 개국이며 유무상 기관이 분리된 국가는 프랑스(시행기관은 통합), 이태리, 한국 등 3개국이다. 2011년 비구속성(국제입찰을 통해 ODA물자 조달) 비율은 우리나라가 48.3\%로 서 $\mathrm{DAC}$ 회원국의 $84.5 \%$ 에 비해 매우 낮은 편이다.

한편 우리나라는 해방이후 OECD 수원국 리스트에서 제외된 2000년까지 약 127 억불을 원 조받은 데 비해 EDCF가 설립된 1987년부터 2011년까지 총 원조규모는 약 94억불('11년 13.2 억불)로 우리나라가 받았던 수원액에 비해 원조액은 여전히 적다. 끝으로 2010년 ODA 사업을 처음으로 전수조사한 결과를 보면 약 1 조 3,600 억원의 재원을 가지고 32 개 기관이 160 여개의 국가국제기구에 1,070 여개 사업을 추진하는 것으로 나타났다.

앞서 샆펴본 공유지의 비극, 본인-대리인 문제, 비용부담자-의사결정자-편익수혜자의 불 일치 등의 문제는 증가추세에 있는 $\mathrm{ODA}$ 예산의 운영 전 과정을 통해 나타나고 있다.

\section{2. 국가 차원의 원조전략 수립 측면}

원조전략 수립측면에서 '공유지의 비극'의 예를 들면, 유무상 통합 국가협력전략(CPS: Country Partnership Strategy)을 수립하는 과정에서 각 시행기관들은 우리나라 ODA역량 자원을 효율적으로 활용하여 원조효과성 제고에 중점을 두기보다 자기부처- 기관이 소관하는 사업이 중점분야에 포함되도록 적극 노력함으로써 갈등발생 등 행정비용이 크게 늘어나고 있 다. 본인-대리인 문제의 예를 보면 수원국의 총괄기관이 대부분 경제부처로서 경제개발에 더 많은 관심을 두고 있어 사회개발 부처의 개발수요를 자신들의 개발수요보다 후순위에 기재함 으로써 CPS정책대화나 개발조사과정에서 수원국 내부에서의 본인-대리인 문제가 발생할 뿐 아니라 시행기관이 주관기관보다 더 많은 정보를 갖고 있어 분야별 주관기관이 시행기관의 정 보를 충분히 알지 못해 각 시행기관이 주관기관을 설득시키기 위해 자신에게 유리하고 필요한 정보만 선별적으로 주관기관에게 제공함으로써 국가차원의 전략 수립에 애로가 되기도 한다. 비용부담자-의사결정자-편익수혜자간의 불일치 문제를 예로 보면 기존 ODA예산사업이 수원 국의 편익 증진에 얼마나 기여했는가에 따라 국가차원의 원조전략이 수립되어야 하나 ODA 사 업의 편익은 수원국 각지에 흩어져 있고 편익 증가 산출의 비교기준도 수원국 각지마다 달라 편익의 정확한 측정이 곤란하고 또한 시행기관마다 수원국의 고객(client)이 다르고 이들 고객 들이 각자의 입장에서 편익을 시행기관에게 알림으로써 편익간 비교가 곤란하여 국가차원의 
전략수립에 애로를 발생시킨다. 상기 편익 측정상의 문제점은 다음에서 살펴볼 ODA사업의 예 산절차상에도 애로를 발생시킨다.

\section{〈표 3〉 상위 20개 수원국 현황(2007 2009년)}

(금액단위 : 백만불, 총액 기준)

\begin{tabular}{|c|c|c|c|c|c|c|c|c|c|c|c|}
\hline \multirow[b]{2}{*}{$\begin{array}{l}\text { 순 } \\
\text { 위 }\end{array}$} & \multirow[b]{2}{*}{ 극가명 } & \multirow[b]{2}{*}{$\|$} & \multicolumn{3}{|c|}{ 2007년 } & \multicolumn{3}{|c|}{ 2008년 } & \multicolumn{3}{|c|}{ 2009년 } \\
\hline & & & 금액 & $\begin{array}{c}\text { 공여 } \\
\text { 기관수 }\end{array}$ & $\begin{array}{c}\text { 평균 } \\
\text { 공여액 }\end{array}$ & 금액 & $\begin{array}{c}\text { 공여 } \\
\text { 기관수 }\end{array}$ & $\begin{array}{c}\text { 평균 } \\
\text { 공여액 }\end{array}$ & 금액 & $\begin{array}{c}\text { 공여 } \\
\text { 기관수 }\end{array}$ & $\begin{array}{l}\text { 평균 } \\
\text { 공여액 }\end{array}$ \\
\hline 1 & 베트남 & 149.23 & 28.41 & 21 & 1.35 & 58.60 & 18 & 3.26 & 62.21 & 23 & 2.70 \\
\hline 2 & 캄보디아 & 86.99 & 35.28 & 13 & 2.71 & 34.66 & 7 & 2.04 & 17.05 & 18 & 0.95 \\
\hline 3 & 스리랑카 & 86.47 & 39.82 & 9 & 4.42 & 25.79 & 15 & 1.72 & 20.86 & 12 & 1.74 \\
\hline 4 & 인도네시아 & 85.91 & 31.32 & 17 & 1.84 & 22.96 & 21 & 1.09 & 31.74 & 19 & 1.67 \\
\hline 5 & 필리핀 & 79.26 & 30.05 & 13 & 2.31 & 26.19 & 18 & 1.45 & 23.02 & 17 & 1.35 \\
\hline 6 & 앙골라 & 71.67 & 17.41 & 2 & 8.70 & 25.92 & 3 & 8.64 & 28.34 & 4 & 7.09 \\
\hline 7 & 이라크 & 69.93 & 53.62 & 4 & 13.40 & 9.76 & 3 & 3.25 & 6.55 & 3 & 2.18 \\
\hline 8 & 몽골 & 62.65 & 13.45 & 20 & 0.67 & 16.71 & 20 & 0.84 & 32.49 & 21 & 1.55 \\
\hline 9 & 라오스 & 54.62 & 17.90 & 11 & 1.63 & 11.57 & 15 & 0.77 & 25.14 & 13 & 1.93 \\
\hline 10 & 키 & 41.02 & 4.01 & 4 & 1.00 & 11.42 & 6 & 1.90 & 25.59 & 0 & 4.27 \\
\hline 11 & 중국 & 39.57 & 14.45 & 17 & 0.85 & 19.35 & 21 & 0.92 & 5.78 & 21 & 0.28 \\
\hline 12 & 방글라데시 & 35.92 & 10.99 & 8 & 1.37 & 9.83 & 11 & 0.89 & 15.10 & 11 & 1.37 \\
\hline 13 & 니카라과 & 32.99 & 9.08 & 2 & 4.54 & 9.07 & 4 & 2.27 & 14.84 & 3 & 4.95 \\
\hline 14 & 아프가니스탄 & 30.69 & 2.58 & 4 & 0.65 & 4.02 & 7 & 0.57 & 24.09 & 6 & 4.02 \\
\hline 15 & 네팔 & 28.78 & 4.98 & 8 & 0.62 & 5.25 & 13 & 0.40 & 18.56 & 11 & 1.69 \\
\hline 16 & 페루 & 25.94 & 10.22 & 6 & 1.70 & 8.73 & 6 & 1.46 & 6.99 & 5 & 1.40 \\
\hline 17 & 탄자니아 & 25.76 & 9.42 & 6 & 1.57 & 7.15 & 9 & 0.79 & 9.19 & 11 & 0.84 \\
\hline 18 & 도미니카 & 22.64 & 1.48 & 3 & 0.49 & 14.25 & 7 & 2.04 & 6.91 & 5 & 1.38 \\
\hline 19 & 보스니아 & 21.74 & 7.76 & 3 & 2.59 & 0.03 & 2 & 0.01 & 13.95 & 2 & 6.98 \\
\hline 20 & 우즈베키스탄 & 20.15 & 5.26 & 8 & 0.66 & 6.66 & 9 & 0.74 & 8.23 & 13 & 0.63 \\
\hline
\end{tabular}

자료 : 감사원, 2011

공유지의 비극을 예방하기 위해서는 집권화된 예산과정을 통해 총량적 결정을 내릴 수 있고 자기 부처의 이익 증대를 우선적으로 도모하기 보다 전체 체계 속에서 자기 부처의 역할이나 기능을 바라볼 수 있는 시스템이 제도화되고 이에 따른 인센티브가 주어져야 한다. 그러나 재 작년 하반기 $\mathrm{ODA}$ 통합추진체계가 운영되기 전에는 유무상 기관별 원조전략은 있으나 이를 종합·조율하는 국가 차원의 원조전략은 미비되었고, 지역별 정책기조, 중점협력국, 국별지원전 략(CAS : Country Assistance Strategy) 등 핵심전략이 기관별로 분리되었다. 유상원조 주관 
기관인 기획재정부(EDCF : 수출입은행 담당)와 무상원조 주관기관인 외교부(KOICA)에서는 2007 2010년 각각 16 개국과 19 개 국을 중점협력국으로 선정하고 이들에 대한 CAS를 각각 수립.집행함으로써 아래 표에서와 같이 '07 '09년간 상위 20개 수원국에 전체 양자간 ODA중 약 $67 \%$ 에 해당하는 금액을 지원하였으나 과테말라의 경우 $\mathrm{KOICA}$ 와 $\mathrm{EDCF}$ 의 공통 중점협력 국이면서도 수원국중 상위 20 위에는 포함되지 않은 반면, 중점협력국이 아닌 터키, 중국, 니 카라과, 네팔 등 6 개국이 상위 20 위에 속하는 등 실질적으로 중점협력국의 지정과 ODA의 집 행이 유기적으로 연계되지 않고 있다. (감사원, 2011)

\section{〈표 4〉유·무상별 중점협력국(2007 2010년)}

\begin{tabular}{c|l|l}
\hline 지역 & \multicolumn{1}{|c|}{ 무상(외교통상부) } & \multicolumn{1}{c}{ 유상(EDCF) } \\
\hline \multirow{2}{*}{ 아시아 } & $\begin{array}{l}\text { 베트남, 인도네시아, 필리핀, 캄보디아, } \\
\text { 스리랑카, 방글라데시, 라오스, 몽골 }\end{array}$ & $\begin{array}{l}\text { 베트남, 인도네시아, 필리핀, 캄보디아, } \\
\text { 스리랑카, 방글라데시, 몽골, 파키스탄 }\end{array}$ \\
\hline \multirow{2}{*}{ 아프리카 } & $\begin{array}{l}\text { 이집트, 탄자니아, 세네갈, 에디오파 } \\
\text { 아, 나이지리아 }\end{array}$ & $\begin{array}{l}\text { 앙골라, 탄자니아, 모잠비크, 마다가스 } \\
\text { 카르 }\end{array}$ \\
\hline 중남미 & 과테말라, 페루, 파라과이 & 과테말라, 콜롬비아 \\
\hline 중동 & 이라크 & 예멘 \\
\hline 유럽 & 우즈베키스탄, 카자흐스탄 & 우즈베키스탄, 아제르바이잔 \\
\hline
\end{tabular}

자료 : 감사원, 2011

이는 '선택과 집중'의 원리에 따라 특정 수원국 내에서 활동하는 원조공여국 및 공여기관의 수를 줄여 사업의 중복 및 자원의 낭비를 방지하고, 원조의 효과성을 높일 것을 제안하는 DAC 의 입장과 정면으로 배치되는 것이다. 이처럼 유상(재정부)과 무상(외교부 등 30 여개 기관)이 각각의 원조시스템에 따라 운영되었기 때문에 부처 차원에서의 합리성을 담보하고 있을 뿐 국 가 차원의 합리성을 충족시키기는 미흡했다.

또한, 유상원조는 경제적 분야, 경협이 잠재성이 높은 국가를 중심으로, 무상원조는 사회적 분야, 최빈국이나 고채무빈국을 대상으로 하는 것이「대외경제협력기금법」이나「한국국제협력 단법」의 취지에 부합하므로 원조대상국가의 소득수준, 국가채무정도, 경제 및 사회발전 정도 등을 고려하여 유·무상 원조의 성격에 맞게 원조대상국가를 선정하는 것이 바람직하다. 그러나 감사원의 자료(2011)에 따르면 기획재정부는 국제통화기금, 파리클럽 등의 주도로 채무구제절 차가 진행중인 고채무빈국이나 최빈국에 '06 '09년간 유상원조 총 승인액 3 조 5,664 억여원 중 $49.5 \%$ 인 1 조 7,647 억여원을 지원하도록 승인한 반면, 외교부는 같은 기간 무상원조 총 지 원액 9,283 억원 중 $31.1 \%$ 에 불과한 2,890 억원만 최빈국이나 고채무빈국에 지원하고 오히려 
중저 소득국 이상에 5,172 억원(55.7\%)을 지원하는 등 유무상원조의 성격에 맞지 않게 지원대 상국을 선정하였다.

〈표 5〉 양자간 ODA의 소득그룹별 지원규모 (순지출 기준, 2008)

\begin{tabular}{c|c|c|c|c|c|c}
\hline \multirow{2}{*}{ 구 분 } & $\begin{array}{c}\text { 최빈국 } \\
\text { (UN지정) }\end{array}$ & $\begin{array}{c}\text { 기타 } \\
\text { 저소득국 } \\
(1 \text { 인당GN/<825달러) }\end{array}$ & $\begin{array}{c}\text { 하위 } \\
\text { 중소득국 } \\
(\leq 3,255 \text { 달러 })\end{array}$ & $\begin{array}{c}\text { 상위 } \\
\text { 중소득국 } \\
(\leq 10,065 \text { 달러 })\end{array}$ & 미분류 & 합계 \\
\hline 무상원조 & 91.5 & 33.4 & 132.2 & 21.1 & 90.5 & 368.7 \\
\hline 유상원조 & 52.7 & 35.1 & 75.6 & 7.1 & - & 170.6 \\
\hline 합계 & 144.2 & 68.5 & 207.8 & 28.2 & 90.5 & 539.3 \\
& $(26.7)$ & $(12.7)$ & $(38.5)$ & $(5.2)$ & $(16.8)$ & $(100.0)$ \\
\hline
\end{tabular}

자료 : 수출입은행

〈표 6〉 양자간 ODA의 소득그룹별 지원규모 (순지출 기준, 2009)

\begin{tabular}{|c|c|c|c|c|c|c|}
\hline 구 분 & $\begin{array}{c}\text { 최빈국 } \\
\text { (UN지정) }\end{array}$ & $\begin{array}{c}\text { 기타 } \\
\text { 저소득국 } \\
\text { (1인당GNI<825달러) }\end{array}$ & 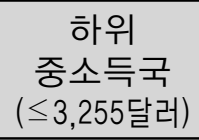 & 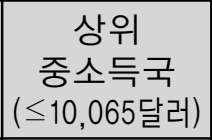 & 미분류 & 합계 \\
\hline 무상원조 & 86.5 & 45 & 117.3 & 17.7 & 100.5 & 367 \\
\hline 유상원조 & 74.7 & 31.5 & 86.9 & 21.1 & - & 214.1 \\
\hline 합계 & $\begin{array}{l}161.2 \\
(27.7)\end{array}$ & $\begin{array}{c}76.5 \\
(13.2)\end{array}$ & $\begin{array}{l}204.2 \\
(35.1)\end{array}$ & $\begin{array}{l}38.8 \\
(6.7)\end{array}$ & $\begin{array}{l}100.5 \\
(17.3)\end{array}$ & $\begin{array}{c}581.1 \\
(100.0)\end{array}$ \\
\hline
\end{tabular}

자료 : 수출입은행

이러한 국가 차원의 원조전략 부재 문제점에 대해 정부는 재작년 10 월 「국제개발협력 선진 화방안」을 통해 지역별 정책기조, 유무상 통합 중점협력국가, 유무상 통합 국가지원전략을 3 가지 핵심요소로 하여 개괄적인 국가 원조전략 수립을 추진하였다. (국무총리실, 2010) 지역별 정책기조로서, 아시아는 그동안의 긴밀한 협력관계를 바탕으로 최우선 중점기조를 그대로 유 지키로 하여 양자원조의 $55 \%$ 내외를 지원하고, 아프리카는 빈곤감축을 위한 인도적 지원을 강 화하면서 양자원조의 $20 \%$ 내외를, 중남미는 우리의 개발경험과 발전모델에 대한 관심증가 등 개발협력 수요에 대응하여 양자원조의 $10 \%$ 내외를, 중동CIS에는 양자원조의 $10 \%$ 내외를, 그리 고 오세아니아와 기타 지역에는 양자원조의 $5 \%$ 내외를 지원하겠다는 가이드라인을 제시했다. 또한 지금까지 유상과 무상이 각각 운영해 오던 중점국가를 통합하여 중점협력국가를 26 개국 으로 축소하는 한편 이들 국가에 대한 지원을 유무상 각각 $70 \%$ 이상으로 설정하였다. 중점협 
력국가는 당시 OECD DAC 수원국 리스트에 있던 152 개국중 소득수준이 가장 높은 그룹의 국 가들은 모두 제외하고 중하위 소득이하 국가 109 개국을 대상으로 국제적인 원조기준, 원조수 행 여건 등을 고려하고 지역안배, 소득수준 등이 종합적으로 검토되어 선정되었다.

끝으로 중점협력국에 선정된 국가에 대해서는 국가협력전략(CPS)을 수립할 계획인데, 이전 까지 유상과 무상이 각각 수립해 온 것을 통합적으로 수립토록 하였다. 2013년까지 수원국의 개발계획 수립시점과 연계하여 CPS를 수립하되 ' 12 년말까지 베트남 등 14 개국에 대해 작성을 마쳤다.

그러나 2015년까지 ODA/GNI 비율을 $0.25 \%$ 까지 확대하겠다는 공약을 했을 뿐 총괄기관에 의한 연도별 재원추계나 원조분야별 총액한도 등 중장기 재정전략은 여전히 마련되지 못하고 있다. 또한「선진화방안」에 제시된 중점협력국가, 지역별 정책기조에 대한 부처 간 인식 공유 도 충분치 못하고 성과지표에 대한 논의는 아직 숙성되지 못하고 있다.

\section{ODA사업 예산의 절차 및 구성 측면}

공유지의 비극 문제를 예로 보면 무상원조협의회에서 분야별 전략이나 구체적 협의기준이 부재한 상태에서 단순히 사업대상지 등의 중복 해소에 초점을 두고 협의함으로써 지속적으로 공유지의 비극 문제가 확대되는 경향이 있다. 본인-대리인 문제를 예로 보면 사전타당성 조 사, 평가 등에 있어서 $\mathrm{ODA}$ 예산을 보다 많이 확보하기 위해 대개 사전타당성 조사가 계획하는 $\mathrm{ODA}$ 사업의 실현가능성 등 타당성을 조사하여 걸러내는 역할을 하기보다 이를 추진하는 통과 의례로 운영되고 평가의 경우에도 대부분의 시행기관들이 자체평가를 실시하여 평가 관대화 개연성을 안고 있고 실제 평가에 따른 환류도 미흡하여 예산총괄부처(기재부 예산실)의 예산 심사에 있어 결정적인 판단근거로 활용되지 못하고 있다. 비용부담자-의사결정자-편익수혜 자의 불일치 문제의 예는 앞서 살펴본 바와 같다.

현재 국제개발협력기본법 및 동 법 시행령에 따르면 주관기관(유상 : 기획재정부, 무상 : 외 교부)은 매년 2월말까지 시행계획 작성 지침을 시행기관에 알려 주고(시행령 99 (1), 시행기관 은 다음 연도의 시행계획을 수립하여 매년 5 월 31 일까지 주관기관에 제출하여야 한다. (시행령 $\S 9(3)$ 그리고 주관기관은 시행기관간 사업 중복 등으로 시행계획의 변경이 필요하다고 인정하 는 경우는 이를 국제개발협력위원회(위원장 : 국무총리)에 제출하여 조정하여야 한다. (법 11 
(3) 이때 국제개발협력위원회(국무조정실)는 법 $\$ 75)$, $11(3)$, 국무조정실 직제 등에 따라 분야 별 조정은 물론 유무상간 조정을 수행한다. 이후 기관별로 기획재정부 예산실에 예산을 신청 하고 국회에서 예산이 확정되면 위원회에서 최종 의결하게 된다.

그러나 실제 시행계획 작성지침은 중장기 재정계획과 국가원조전략이 미비된 관계로 내용 이 추상적이거나 ODA사업에 포함될 수 있는 내용의 범위, 향후 일정 안내 등에 그치고 유무 상 주관기관간의 통합된 작성지침도 부재한 상태이다. 또한 기타 정부부처 등 시행기관도 중 장기 원조계획이 부재하여 원조 대상국가지역을 명시하지 않은 채 사업계획을 작성하는 경우 등 시행계획이 구체적이지도 않다. 그리고 'ODA사업 예산을 신청해서 재원을 배분받으면 나 쁠 게 없다'는 인식하에 미숙한 시행계획을 다수 제출하는 경향도 있다. 아울러 유무상 원조 주관기관인 기획재정부, 외교부가 소관분야 중복 등을 조정해야 하지만 각 부처의 시행계획에 대해 구체적인 내용 파악이 곤란하여 시행계획상 사업 명칭의 유사성 여부를 토대로 소폭 조 정을 추진하고 있으며 이마저도 소관 부처의 반발에 부딪쳐 소극적인 조정에 그치고 있다. 예 산실의 예산심의나 국회에서의 심의도 국가원조전략이나 중장기 계획에 근거하여 이루어지지 못하고 'case by case'의 심의에 그치는 경우가 일반적이다. 결국 중장기 재정계획, 국가차원 원조전략하의 분야별·지역별 예산총액 배분이 없이 다른 어떤 정부예산보다 더 bottom-up 예 산방식이 이루어지고 있다.

다음으로 2011년 기준으로 ODA사업을 살펴보면 먼저 양자 ODA는 44개 기관에서 약 1 조원 규모, 900 여개의 사업을 추진 중에 있다. KOICA가 4,483억원(41\%), EDCF가 4,750억원 (43\%)을 집행중으로 이들 2 개 기관의 예산이 전체 양자 $\mathrm{ODA}$ 의 $84 \%$ 를 차지하고 기타 시행기 관(지자체 포함)이 1,724 억원 규모로서 전체 양자 $\mathrm{ODA}$ 의 $16 \%$ 를 차지하고 있다.

〈표 7〉2011년 정부부처 및 기관별 양자 및 다자 ODA 실적

\begin{tabular}{c|r|r|r}
\hline \multirow{2}{*}{ 구분 } & \multicolumn{3}{|c}{2011} \\
\cline { 2 - 4 } & \multicolumn{2}{|c|}{ 양자간 } & \multicolumn{2}{c}{ 다자간 } & \multicolumn{1}{c}{ 총ODA } \\
\hline 강원도 & 5.10 & - & 5.10 \\
\hline 경기도 & 4.86 & - & 4.86 \\
\hline 경상북도 & 20.66 & - & 20.66 \\
\hline 경찰청 & 14.33 & 57.18 & 14.33 \\
\hline 고용노동부 & 20.87 & - & 18.05 \\
\hline 공정거래위원회 & 1.12 & - & 1.05 \\
\hline 관세청 & 1.05 & & - \\
\hline
\end{tabular}




\begin{tabular}{|c|c|c|c|}
\hline \multirow{2}{*}{ 구분 } & \multicolumn{3}{|c|}{2011} \\
\hline & 양자간 & 다자간 & 총ODA \\
\hline 교육과학기술부 & 370.01 & 80.88 & 450.89 \\
\hline 국가보훈처 & 0.60 & - & 0.60 \\
\hline 국무총리실 & 20.11 & 6.31 & 26.42 \\
\hline 국민권익위원회 & 0.33 & - & 0.33 \\
\hline 국방부 & 15.97 & - & 15.97 \\
\hline 국토해양부 & - & 1.13 & 1.13 \\
\hline 국회 & 2.22 & - & 2.22 \\
\hline 금융위원회 & 1.53 & - & 1.53 \\
\hline 기상청 & 0.63 & 0.79 & 1.42 \\
\hline 기획재정부 & 249.53 & 539.16 & 788.69 \\
\hline 농림수산식품부 & 112.88 & 95.58 & 208.46 \\
\hline 농촌진흥청 & 78.93 & 3.54 & 82.47 \\
\hline 대검찰청 & 3.33 & - & 3.33 \\
\hline 대구광역시 & 0.34 & - & 0.34 \\
\hline 대외경제정책연구원(KIEP) & 7.10 & - & 7.10 \\
\hline 대전광역시 & 0.08 & - & 0.08 \\
\hline 문화재청 & 2.80 & 0.98 & 3.78 \\
\hline 문화체육관광부 & 15.19 & - & 15.19 \\
\hline 방송통신위원회 & 41.88 & 14.50 & 56.38 \\
\hline 법무부 & 11.24 & - & 11.24 \\
\hline 보건복지부 & 75.05 & 132.37 & 207.42 \\
\hline 부산광역시 & 1.80 & - & 1.80 \\
\hline 산림청 & 38.63 & 29.73 & 68.37 \\
\hline 서울특별시 & 10.71 & - & 10.71 \\
\hline 여성가족부 & 8.23 & 53.46 & 61.69 \\
\hline 외교통상부 & 243.83 & 597.29 & 841.13 \\
\hline 울산광역시 & 0.07 & - & 0.07 \\
\hline 인천광역시 & 29.08 & - & 29.08 \\
\hline 전라남도 & 0.15 & - & 0.15 \\
\hline 중소기업청 & 0.22 & - & 0.22 \\
\hline 지식경제부 & - & 1.76 & 1.76 \\
\hline 충청남도 & 0.05 & - & 0.05 \\
\hline 통계청 & 1.04 & 0.56 & 1.60 \\
\hline 특허청 & 8.97 & 0.08 & 9.05 \\
\hline
\end{tabular}




\begin{tabular}{c|r|r|r}
\hline \multirow{2}{*}{ 구분 } & \multicolumn{3}{|c}{2011} \\
\cline { 2 - 4 } & \multicolumn{1}{|c|}{ 양자간 } & \multicolumn{1}{|c}{ 다자간 } & \multicolumn{1}{c}{ 총ODA } \\
\hline 한국개발연구원(KDI) & 70.68 & 8.40 & 79.08 \\
\hline 한국국제협력단(KOICA) & $4,483.03$ & 34.88 & $4,517.91$ \\
\hline 한국수출입은행(EDCF) & $4,750.06$ & 55.37 & $4,805.42$ \\
\hline 한국은행 & - & $1,955.00$ & $1,955.00$ \\
\hline 행정안전부 & 179.98 & - & 179.98 \\
\hline 환경부 & 53.22 & 40.70 & 93.92 \\
\hline 합계 & $10,957.47$ & $3,709.66$ & $14,667.14$ \\
\hline
\end{tabular}

* 자료 : 국무조정실, ODA 통계 시스템(EDCF)

$\mathrm{KOICA}$ 와 $\mathrm{EDCF}$ 양 기관은 유·무상 $\mathrm{ODA}$ 대표기관으로서, 규모면에서 $\mathrm{ODA}$ 의 대부분을 차 지하고 있어 중복과 연계가능성 검토에 있어 핵심적 부분이 되고 있다. 2011년 기준으로 양자 $\mathrm{ODA}$ 의 주요 3 개 부처의 경우 [외교부( 244 억 : $\mathrm{HLF}-4$ 준비, 국제NGO 지원 등), 기획재정부 (250억 : 경제발전경험 공유사업 등), 교과부(370억 : 정부장학생 초청사업 등)] 사업내용 및 형태에 있어 $\mathrm{KOICA}, \mathrm{EDCF}$ 와 중복의 여지가 낮지만 기타 농식품부, 복지부, 행안부(현 안행 부), 방통위(현 미래부), 농진청, 산림청 등 기타 시행기관의 경우 양자 ODA 핵심분야인 농업. 보건의료·ICT 분야로서 $\mathrm{EDCF}$ 와 연계가능성·KOICA와 중복가능성이 높은 부분이다

끝으로 전체 양자 $\mathrm{ODA}$ 의 $1 \%$ 에 해당(' 11 년 기준)하는 문화부, 법무부, 지자체 등의 경우 대 부분 초청연수, 국제기구 협력사업이 위주여서 $\mathrm{KOICA}$ 사업과의 중복가능성이 특히 높은 것으 로 분석되고 있다.

한편 2011년 기준으로 국제(금융)기구 등에의 출연·출자 등 다자 ODA는 22개 기관에서 약 3,700 억원 규모, 150 여개의 사업을 추진하고 있다. 기획재정부가 $\mathrm{ADB}, \mathrm{WB}$ 등 $\mathrm{MDB}$ 관련 다 자 $\mathrm{ODA}$ (한국은행 포함) 사업으로서 전체 다자 $\mathrm{ODA}$ 의 $65 \%$ 이상을 차지하고, 외교부 등 나머 지 기관이 UN 및 기타 국제기구 관련 다자 $\mathrm{ODA}$ 사업으로서 전체 다자 $\mathrm{ODA}$ 의 $35 \%$ 정도를 차지하고 있다.

이렇게 1 조 5 천여억원의 재원으로 160 여개 국가국제기구에 1 천개를 상회하는 사업을 추진 하게 된 것은 앞서 본 바와 같이 국가 차원의 원조전략 등이 부재한 상태에서 다음에 살펴볼 사업수행체계간 분절화 등에 기인한 바 크다. 그 결과 선택과 집중에 따른 원조효과성 제고가 어렵게 되었고 원조의 집중성도 국제적 수준에 비해 낮은 실정이다. 


\section{4. 사업수행 체계간 연계 측면}

공유지의 비극 문제를 예로 보면 각 시행기관들이 사업간 연계를 통한 시너지효과 제고 보 다는 기존의 자기기관의 수행체계대로 운영하는 데 관심을 더 두는 이유가 예산운영의 독자성 을 확보하는 데 중점을 두기 때문이며 이로 인해 공유지의 비극이 확대될 우려가 크다. 본인대리인 문제를 예로 보면 사업간 연계, 공동사업을 추진하게 되면 각자의 사업수행체계에 타 부처, 기관이 참여함으로써 자기기관의 약점이나 감추어진 특성, 정보 등이 노출되는 것을 걱 정하는 게 일부분 원인으로 작용하여 연계가 잘 안되고 있다. 이와 연결시켜 비용부담자-의사 결정자-편익수혜자의 불일치 문제를 보면 연계거부를 위해 연계에 따른 예상편익증대보다 예 상 행정비용 증대 등을 더 강조하기도 하는 점을 예로 들 수 있다. 이는 본인-대리인 문제와 연결되기도 한다.

우리나라의 경우 대외원조정책을 총괄하는 국제개발협력위원회가 있고, 유무상 원조 주관 기관 및 $\mathrm{EDCF} \cdot \mathrm{KOICA}$ 등 시행기관이 따로 있으며, 30 여개 정부기관에서도 독자적으로 원조를 실시하는 등 DAC회원국 중 분절화가 심한 원조체계를 가지고 있다. (김은미 외, 2009) 2009년 $\mathrm{DAC}$ 특별검토보고서에서는 원조체제 분산화, 원조기관 간 조율 부재 및 비효율성에 대한 지 적과 함께 한국 ODA정책 전반을 총괄할 수 있는 통합된 정책체계, 포괄적, 장기적 전략 수립 의 필요성을 권고한 바 있다. 91 년 09년중 유상과 무상의 연계사업은 결과적으로는 총 22 건 이 있었지만 유무상 연계를 전제로 양 기관이 협의하여 추진한 사례는 1 건도 없다. 그동안 유 무상이 연계된 경우는 수원국의 요청에 따라 먼저 개발조사사업을 시행한 이후 이를 토대로 수원국이 우리나라에 유상사업을 요청하여 이루어진 것 뿐이었다. 분절화된 원조체계는 본인 -대리인 문제를 발생시킬 여지를 많이 만들어내는 여건이 된다. 예산의 완전성을 기하기 어렵 게 만들고 정보의 비대칭은 물론 총괄기관주관기관의 통합적 관리·감독의 미비로 인해 대리인 의 감추어진 행동이 발생할 가능성이 커지게 된다. 그 결과 각 부처에서 상호 긴밀한 연계 없 이 $\mathrm{ODA}$ 사업을 산발적으로 추진하고 있고, 사업성과가 미흡해도 책무성 확보가 곤란한 경우 가 발생하고 있다. 또한 유·무상 주관기관(기재부·외교부)과 KOICA-EDCF는 기타 부처가 제안 하는 사업을 적극적으로 수용하지 않으면서 자기 기관의 사업내용 공개·공유에는 소극적이며, 분야별 전문성을 갖춘 소관부처와의 사업검토 협의에도 소극적이다. 이에 따라 각 부처는 산 하기관을 통해 자체 사업을 추진하고 있는데, ODA 사업 수행의 전문성이 낮아 일회적이고 단 기적인 초청연수사업에 집중함으로써 부처의 전문성이 크게 활용되지 못하고, 대부분 ODA 효 과성이 낮은 사업을 수행하는 경우가 빈발하고 있다. 특히 독자적으로 국제개발협력사업을 추 진하기에 전문성이 없는 기관이 $\mathrm{ODA}$ 사업을 추진함으로써 대부분 $\mathrm{ODA}$ 목적에 적합하지 않는 
행사성 사업에 예산이 지원되어 원조사업의 계획성 및 효과성이 저하되는 경우가 많고, ODA 에 대한 개념 이해와 전문성이 부족한 기관에서 국제 협력 성격의 사업을 일단 추진한 후 사후 적으로 ODA사업으로 분류하는 경우도 많다. 예를 들면 광역지자체들의 경우 2010년 약 1,029 만 달러 규모의 40 개 사업을 실시하였는데 주로 자매도시 등과 국제협력차원의 단순한 장비 지원, 초청연수 사업의 형태가 많고 해당 사업에 대한 전문성도 부족하여 사업추진, 사후 관리 부실 등의 문제가 빈발하고 있다.

또한 각 부처에서 상호 연계 없이 ODA 사업을 개별적으로 추진하는 과정에서 유사중복사 업 들이 발생하여 자원.예산 낭비가 초래되거나 자원의 초과배분 등의 문제가 야기되고 있다. 예를 들면 앞서 본 표3과 같이 베트남의 경우 우리나라의 공여기관수가 2007년도 21개, 2008 년도 18 개, 2009 년 23 개 기관이고, 인도네시아 등에도 많은 공여기관이 원조에 참여하고 있는 것으로 나타났다. 또한 다음의 표9〈베트남에 대한 중복지원 현황(2007 2009년)〉 에서 보듯 이 베트남에 IT, 보건의료 등 특정분야에 여러 기관의 원조가 중복됨으로써 사업간 연계 및 시 너지 효과를 거두기 어렵다. (감사원, 2011) 마지막으로 우리나라와 관련하여 수원국이 제기하 는 사항을 살펴보면 우리나라가 개별부처별로 수원국을 직접 접촉하다보니 혼란스럽다는 문제 가 제기되었다. 이는 개별부처가 통일된 원조체계의 통로를 거치기보다 자기 부처의 업무영역 확대 등 이익 확대를 위해 수원국의 해당 부처와 개별적으로 접촉한 결과이기도 하다. 이러한 원조분절화는 공여국에게는 거래비용의 증가, 행정절차의 중복, 원조의 질 저하를 초래하여 '규모의 경제' 실현을 방해하고, 수원국에게는 개발원조기구, 기관마다 개별적이고 독자적인 행정보고 절차를 요구함에 따라 행정절차와 서류작업에 막대한 시간을 투자하게 되며, 특히 공여국 내 다수 기관이 동일한 수원국에 원조사업을 집행하는 과정에서 상이한 원조목적과 재 정지원 기간, 행정절차 등을 요구하여 수원국 정부가 혼란을 경험할 수 밖에 없다. 
〈표 8〉베트남에 대한 중복지원 현황(2007 2009년)

(금액단위 : 천불)

\begin{tabular}{|c|c|c|c|}
\hline 분야 & 공여기관명 & 지원사업명 & $\begin{array}{c}\text { 지출액 } \\
\text { (또는 약정액) }\end{array}$ \\
\hline \multirow{13}{*}{ IT분야 } & \multirow{3}{*}{ 한국국제협력단 } & 호치민 정치아카데미 전자도서관 & 492 \\
\hline & & 한·베트남 친선 IT대학 & 490 \\
\hline & & 베트남 IT 감사세미나 등 ITR관련 연수사업 & 623 \\
\hline & \multirow{2}{*}{$\begin{array}{l}\text { 지식경제부 } \\
\text { (구 산업자원부 포함) }\end{array}$} & 전자지역정보화 사업 타당성 조사 & 108 \\
\hline & & E-PORT 시스템 구축 타당성 조사 & 108 \\
\hline & 한국수출입은행 & 멀티미디어 센터 건립 & 25,000 \\
\hline & \multirow{3}{*}{$\begin{array}{l}\text { 문화관광부 } \\
\text { (구 정보통신부 포함) }\end{array}$} & 국제 IT정책 및 기술 프로그램 & 300 \\
\hline & & 한국인터넷 봉사단 & 69 \\
\hline & & 국제대학원 IT장학사업 & 907 \\
\hline & \multirow{3}{*}{$\begin{array}{l}\text { 교육과학기술부 } \\
\text { (구 교육인적자원부 포 } \\
\text { 함) }\end{array}$} & APEC 사이버 교육협력 & 20 \\
\hline & & APEC e-러닝 연수 프로그램 & 51 \\
\hline & & ICT 국제교류 & 18 \\
\hline & 여성가족부 & APEC 여성 IT 능력 제고 & 12 \\
\hline \multirow{8}{*}{ 보건의료 } & 한국수출입은행 & 닥농 지역병원 건립 & 5,686 \\
\hline & 인천광역시 & 하이퐁 어린이 심장수술 프로그램 & 15 \\
\hline & 대전광역시 & 빈둥지역 의료봉사 & 3 \\
\hline & 농림부 & 조류인플루엔자 대응협력 & 6 \\
\hline & \multirow{2}{*}{ 노동부 } & 직업 건강과 안전에 대한 기술협력 & 3 \\
\hline & & 직업 건강과 안전에 대한 기술개선 & 12 \\
\hline & 경기도 & 의료지원 & 30 \\
\hline & 한국국제협력단 & 중부지역 종합병원 및 봉사단, 연수 등 & 4,659 \\
\hline
\end{tabular}

자료 : 감사원, 2011

\section{ODA예산 사업의 평가 측면}

평가 측면에서는 본인-대리인 문제가 크게 발생하고 있다. 정책, 사업평가의 경우 KOICA$\mathrm{EDCF}$ 등 부처 산하 시행기관들이 주관기관보다 수원국 현지사정, 사업집행정보 등을 더 많이 갖고 있어 자신에게 유리하게 선별적으로 정보를 제공하는 것이 가능해 기관평가 등에서 정확 한 진단을 어렵게 만들기도 한다. 이외에 비용부담자-의사결정자-편익수혜자의 불일치 문제 
를 예로 보면 수원국의 편익수혜자는 보다 많은 원조를 받기 위해 기존 원조의 편익을 과장하 거나 시행기관의 원조효과 평가 답변에 있어서 수원국 전체의 편익이라는 측면보다 답변하는 기관 자신들의 이해관계에 따라 부정확한 답변을 하기도 한다.

평가는 정보의 비대칭을 극복하고 책무성을 확보케 하여 본인-대리인 문제를 해소할 수 있 는 수단인 동시에, 종합적이고 집권화된 예산과정에서 평가결과를 통해 차등지원이나 탈락을 거침으로써 공유지의 비극을 완화시킬 수 있다는 측면에서 바람직한 ODA를 위한 핵심요소이 다. 그러나 ODA통합평가 추진체계가 운영되기전까지는 유상과 무상이 각각 분리된 채 자체평 가 위주의 평가가 이루어짐으로써 평가의 사각지대가 생기고 관대화 경향 및 객관성 부족문제 가 발생하는 문제가 있었다. 또한 SOC 등 프로젝트 위주의 평가가 진행되어 주제별, 국별, 유 무상 연계 평가 등 다양한 평가가 부족하였고 평가결과의 피드백 조치도 미흡하였다. 이렇듯 목적에 따른 충실한 평가도 부족했을 뿐 아니라 평가결과를 미공개하여 책임성과 ODA사업에 대한 국민적 지지 확보가 곤란하였다. 2008년 KOICA가 코리아리서치에 위탁, 실시한 여론조 사에 따르면 ODA에 대한 인지도가 1999년 16.8\%에서 2008년도에는 50.8\%로 인지도가 높아 졌으나 원조규모의 적정성에 대해서는 여성보다는 남성이, 연령대별로는 50 대 이상이 젊은 층 보다, 직업별로는 화이트칼라나 학생보다는 블루칼라와 주부가 한국의 원조규모가 높다고 인 식하고 있는 것으로 밝혀졌다. (한국국제협력단, 2011) 또한 2012년 대외경제연구원이 실시한 여론조사에 따르면 우리나라 국민의 4 명중 약 1 명 정도 비율인 27.4\%가 우리나라의 ODA규모 가 과다하다는 의견을 나타냈고 이는 $\mathrm{EU}$ 에서 $\mathrm{ODA}$ 규모가 과다하다 의견이 $7 \%$ 로 나타난 것과 큰 대조를 이룬다. 이러한 조사결과들을 종합할 때 높은 인지도가 곧 원조규모 확대에 대한 지 지로 반드시 이어지는 것은 아니라는 점을 시사한다고 볼 수 있다.

\section{$\mathrm{V}$. 개선방안}

$\mathrm{ODA}$ 예산은 공유지의 비극, 본인-대리인 문제, 비용부담자-의사결정자-편익수혜자의 불일 치의 발생 개연성이 다른 정부예산보다 더 높아 우선순위와 효과성에 기반한 자원배분, 효율 성 등의 측면에서 횔씬 불리한 특성을 갖고 있다. 앞서 살펴본 바와 같이 국가 차원의 원조전 략 수립, 사업수행 체계의 분절화 극복, 평가 활성화 등이 서로 연계되어 운영될 때 비로소 $\mathrm{ODA}$ 예산의 효과성, 효율성 등을 제고할 수 있다. 


\section{1. 국가 차원의 원조전략 측면}

$\mathrm{ODA}$ 예산에서 공유지의 비극을 완화하기 위해서는 관련 부처와 기관이해관계자 $\mathrm{NGO}$ 등 시 민사회 등의 참여하에 총괄기관에 의한 중장기 재정계획, 분야별·지역별 예산총액 배분계획 등 국가 차원의 원조전략이 구체성구속성을 갖춰 마련되어야 하고, ODA 세미나워크샵 등을 통 해 동 원조전략에 대한 충분한 인식과 공감대가 형성되어야 한다. 또한 자체평가를 토대로 한 통합평가를 통해 동 원조전략에의 부합 여부에 따라 ODA사업 예산의 증감조치를 시행함으로 써 개별부처가 자기부처 이익 증대화 중심에서 벗어날 수 있는 인센티브를 부여해야 한다.

이러한 토대 위에서 중점 협력국에 대한 ODA 배분을 강화하고, 선정된 26개국의 소득그룹 을 고려하여 유·무상 원조 연계를 강화할 필요가 있다. 최빈국에게는 이들 국가가 상환능력이 없으므로 $\mathrm{EDCF}$ 차관은 가급적 제한하고 무상원조를 중점적으로 지원하는 한편, 저소득국과 하위중소득국에게는 유·무상원조 연계를 강화하면서 단기적이고 일회성 지원사업은 제한하는 것이 바람직하다. 나아가 현재 중점협력국으로 26 개국을 선정하였으나, '선택과 집중'을 위해 향후 협력대상국을 점차 줄여 나갈 필요가 있다. 또한 원조사업의 효과성 제고를 위해서는 다 양한 분야나 지역에 다양한 사업을 하는 것보다는 핵심 분야나 지역에 사업을 집중시켜 지속 적으로 관리하는 것이 필요하다. 이 과정에서 중점협력국의 국가개발정책, 빈곤퇴치정책 상의 개발우선순위와 수요, 타 공여국 지원현황, 우리나라의 비교우위를 반영하여 중점 지원분야를 선정하되 선정과정에서 관계부처와 충분한 협의를 거쳐야 한다. 한편 국가협력전략(CPS)이 마련된 국가의 경우 해당 CPS를 관련 부처 및 기관과 공유하여 유무상 통합 중점 지원분야에 적합한 중기 지원계획을 수립해야 한다.

\section{2. 사업 수행체계 및 사업연계 측면}

$\mathrm{ODA}$ 예산 사업의 책무성을 확보하고 대리인의 감추어진 행동 등을 최소화하기 위해서는 국 가 차원의 원조전략평가활동과 연계하여 사업수행 체계의 연계, 총괄기관의 명확화가 필요하다.

OECD DAC회원국들의 원조체계를 살펴보면 23개 회원국(24개 회원국중 EU집행위 제외) 가운데 14 개국이 전체 원조의 $100 \%$ 를 무상으로 집행하고 있으며, 유상원조를 집행하는 나라 중에서도 우리나라와 일본, 포르투갈을 제외하면 유상원조의 비중이 작은 편이다. 한편, 거의 
대부분을 무상원조하는 국가들은 외무부서에서 정책을 총괄하고 있고, 유무상 원조를 같이 시 행하는 국가들도 외무부서에서 정책을 총괄하면서 집행기관을 통합하는 등 원조분절화에 따른 원조의 효과성 저하 문제를 해결하기 위해 많은 노력을 하고 있다. (감사원, 2011; 권 율 외, 2008)

우리나라와 유사한 원조체계를 가졌던 일본의 경우 과거 외무성과 재무성이 각각 JICA와 $\mathrm{JBIC}$ 를 통해 무상과 유상원조를 독립적으로 운영·집행하는 동시에 경제무역산업성을 비롯한 기타 정부부처가 원조에 참여하였으나 $\mathrm{DAC}$ 동료평가시 이와 같은 분절적 원조집행체계는 $\mathrm{DAC}$ 회원국중 가장 분절되고 복잡한 체계중 하나로 거듭 지적받은 후(OECD 1998, OECD 2003) 2008년 10월 대대적인 체제개혁을 단행해 외무성으로 원조정책 기능을 집중하고 외무 성 산하 New JICA로 유무상 원조기관과 기능을 통합한 바 있다.

우리나라도 2009년 12월에는「국제개발협력기본법」을 제정(2010.7.26. 시행) 하여 국제개발 협력위원회 중심으로 유·무상원조 통합추진체계를 구축하기 위해 노력하고 있다. 그러나 외교 부가 무상원조 주관기관으로, 기획재정부가 유상원조 주관기관으로 정해져 있고 이들에게 예 산 편성 및 집행(산하기관에 출연) 권한이 있으며 각각의 집행기구를 산하기관으로 두고 있을 뿐만 아니라 30 여개에 이르는 개별 정부부처에서도 각각의 예산으로 $\mathrm{ODA}$ 를 집행하고 있어 정책기관 및 집행기관이 분절되어 있는 상태에서 국제개발협력위원회가 심의·조정하는 현 체 제에서는 원조의 효과성을 극대화하고 국제수준에 근접하는 선진 원조체계를 구축하기 위해서 는 위원회의 역할과 기능을 보다 강화할 필요가 있다. 특히 동 위원회에서는 2010년 10 월 17 개 관계부처 합동으로「국제개발협력 선진화방안」을 마련하면서 2015년까지 유상원조 비율을 순지출 기준으로 $40 \%$ 로 유지하기로 한 바 있는데, 이로 인해 2015년까지 높은 수준의 유상원 조 비율이 유지될 것으로 예상되므로 유상원조 주관기관인 기획재정부가 맡은 역할의 비중이 매우 높아 일반적인 DAC회원국의 경우와 같이 외무부서로 하여금 ODA정책 총괄업무를 수행 토록 하는 것은 현실적으로 어렵다고 할 수 있다. 따라서 당분간 현재 유무상 원조 총괄기능 을 수행하는 국무총리실에서 유무상 원조간 연계, 중복조정을 담당해 나가되 이후 유상원조 비중이 줄어드는 등 여건이 성숙되면 다른 $\mathrm{DAC}$ 회원국들과 마찬가지로 집행기관 통합 또는 단일 중앙 부처가 원조정책을 총괄하는 등의 원조기관 단일화가 이루어져야 하고 이에 대한 중장기계획 등을 국제개발협력위원회에서 검토할 필요가 있다. 한편, 수원국 현지에서의 ODA 기관간 연계정보공유 활성화라는 측면에서 독일의 경우 '독일하우스' 라는 한 건물에 다양한 원조기관이 모여 현지 정보를 공유하고 협력을 강화하고 있는 점도 참고할 만하다. 
책무성 강화를 위해서는 관계부처에 ODA 담당관을 지정하고, 프로그램이나 프로젝트마다 $\mathrm{PM}$ 을 명확히 지정할 필요가 있다. 또한 관계 부처.기관간 협조가 우수하거나 유무상 연계 시 너지 효과가 높은 모범사례를 발굴하여 포상함으로써 인센티브를 강화할 수도 있다. 그리고 공여기관의 혼선 최소화 등 수원국 중심의 효과적인 원조를 위해서는 재외공관의 역할을 강화 하여 수원국과의 협의 창구를 단일화할 필요가 크다. 아울러 사업수행 체계간 연계 강화를 위 해서는 정보공유와 참여 확대가 요구된다. 개발협력 콘텐츠 개발과정에서 $\mathrm{KOICA}$ 와 $\mathrm{EDCF}$ 의 사업에 각 부처·청이 제시하는 사업기술 분야를 적극 반영토록 하는 한편, 관련 부처와 기관별 로 전문성이 높은 분야를 사전에 선정하여 중점협력국의 지원프로그램에 부합하는 사업의 경 우에는 우선적으로 지원하는 것이 바람직하다. 2011년말 국제개발협력위원회에서 'ODA기관 간 협력체계 구축방안'을 의결한 것도 ODA시행기관간 정보의 벽(壁)을 허물어 상호간 사업정 보 무지에 따른 중복을 방지하고 사업간 연계를 강화하고자 한 것이다. 또한 수원국과의 정책 협의와 중점지원분야 선정 과정에는 관계부처 외에도 해당 수원국에서 활동하는 NGO, 민간기 업, 연구기관, 학계 등 각계각층의 이해관계자가 참여하도록 해야 한다. 이는 뒤에서 살펴볼 평가의 활성화에도 도움이 된다.

한편 유상사업과 무상사업의 연계 취지는 유상과 무상의 지원영역이 비교적 구분되어 있다 는 점에서 출발한다. 유상은 대규모 자금이 투입되는 인프라 사업에 주로 활용되며 무상은 비 교적 소규모 자금이면서 다양한 분야에 활용된다. 그렇기 때문에 유상과 무상을 연계하면 시 너지를 창출할 가능성이 많다. 예를 들어 무상으로 개발컨설팅을 하고 그 결과를 바탕으로 유 상 프로젝트 사업을 하는 방안이 있고, 대규모 병원을 유상으로 건립하면 그 운영을 무상원조 로 하는 방안도 고려할 수 있으며 하나의 마을을 선정하여 유상자금으로 전력을 공급해 주고 무상으로 학교나 보건소를 지어주는 방안 등을 생각할 수 있다.

\section{ODA예산 사업의 평가 측면}

$\mathrm{ODA}$ 예산사업의 책무성과 투명성 강화를 위해서는 무상과 유상에 관계없이 사전평가, 모니 터링, 사후평가를 통한 사업 전 단계의 프로젝트 사이클 관리(PCM : Project Cycle Management)가 강화되어야 한다. 이를 통해 대리인의 감추어진 행동이나 특성에 대한 정보를 확보할 수 있고 정보의 비대칭성 문제 해소에도 기여할 수 있다. 먼저 결과 중심의 사업관리체 제를 구축하고, 모니터링과 평가 강화를 위한 성과지표 설정을 위해 사전평가를 도입할 필요가 있다. 사전평가를 통해 빈곤층을 위한 성장(pro poor growth)과 MDGs 실현을 위한 성과중심 
의 지표를 설정하고, 결과중심의 모니터링과 평가를 강화해야 한다. 또한 산출 중심의 프로젝트 사업에서 결과 및 파급효과를 중시하고 모니터링을 통해 관리·감독 역량을 강화하는 한편 독립 적인 평가조직을 확대할 필요가 있다. 그리고 자체평가의 객관성을 보다 제고해야 한다. 올해 국무총리실의 통합평가소위원회에서 $\mathrm{ODA}$ 시행기관의 자체평가의 객관성, 효과성 등 평가의 질 제고를 위해 기존에 수행되었던 자체평가 보고서, 평가시스템 등을 다시 평가하는 메타평가를 실시하는 것도 자체평가 관대화 등에 따른 대리인의 감추어진 행동이나 특성 등에 대한 정보를 확보하고 정보의 비대칭성 문제를 극복하고자 하는 데 의의가 있다고 하겠다.

아울러 사업추진 단계별 평가, 중점지원분야별 부문평가, 국별평가 등 평가대상 및 범위를 확대.강화할 필요가 있다. 또한 평가과정에 수원국의 전문가를 포함하는 등 수원국의 의견수렴 을 강화하고 평가결과를 공유함으로써 의사결정자와 편익수혜자간의 불일치 문제 해소에 기여 할 수 있다. 또한 수원국의 지역주민에 대한 설명회를 개최함으로써 정보 제공은 물론, 당해 $\mathrm{ODA}$ 사업이 의도한 성과편익에 관한 객관적인 평가를 유도할 수 있다. 마지막으로 평가결과 는 홈페이지 등에 공개함으로써 평가의 객관성 확보는 물론 추후 사업의 책임성 확보에도 도 움을 줄 수 있다. 그리고 결과 중심의 평가결과를 환류하여 대리인간 경쟁을 촉진함으로써 단 순히 ODA예산을 더 많이 확보하려는 노력을 지양하게 만드는 인센티브를 제공할 수도 있다.

\section{VI. 결론}

우리나라는 반세기만에 원조를 받던 수원국에서 탈피하여 원조를 주는 공여국으로 전환되 었고 여기서 한걸음 더 나아가 선진 공여국간의 회의체인 OECD DAC에 가입한 유일한 국가이 다. 따라서 다른 어떤 공여국보다 수원국의 입장을 더 잘 이해하고 선진 공여국과 수원국간의 가교 역할을 충실히 할 수 있는 장점을 갖고 있다. 이와 함께 우리나라의 ODA예산은 국제사 회에 공약한 바와 같이 앞으로도 계속 확대될 예정이다. 이러한 시점에서 우리나라의 ODA 효 과성을 높이고 다른 어떤 정부예산보다 공유지의 비극 등이 발생할 가능성이 큰 ODA사업 예 산제도를 개선하는 것은 매우 중요하다. 공유지의 비극, 본인-대리인 문제, 의사결정자-편익 수혜자의 불일치 등의 문제를 해결하기 위해서는 국가차원의 원조전략 수립, 사업수행 체계간 의 연계·총괄기능의 강화, 평가 활성화를 위한 제도가 재정비되고, 이러한 제도가 잘 운용될 수 있도록 원활한 정보소통, 인센티브 제공 등을 위한 하위 제도(sub-institution)간의 정교 하고 세밀한 조화가 필요하다. 


\section{참고문헌}

감사원(2011). 공적개발원조(ODA) 추진실태

국무총리실 (2010).『국제개발협력 선진화 방안』, 국제개발협력위원회

권 율 외 (2008). 『최근 국제사회 공적개발원조(ODA) 동향과 향후 전망』, 대외경제정책연구원 김은미 외 (2010). 『선진원조기관의 DAC 권고사항 및 평가지표 적용현황과 $\mathrm{KOICA}$ 의 대응방향 연구』, 한국국제협력단

김은미 외 (2009). 『한국 원조체계의 분절이 원조 효과성에 미치는 영향 및 개선방안』, 한국국제협력단 이경구 (2004). 『한국에 대한 개발원조와 협력^, 한국국제협력단

전상경 (2005).『정책분석의 정치경제』, 박영사

정우진 (2010).『한국형 개발협력 모델』, 한국국제협력단

하연섭 (2008). 『재정학의 이해』, 다산출판사

하연섭 (2010). 『정부예산과 재무행정』, 다산출판사

한국국제협력단 (2009). 『국제개발협력의 이해』, 한울아카데미

한국국제협력단 (2011). 『한국 ODA에 대한 국민인지 제고 전략』, 국제개발협력 2011년 제1호

Garret Hardin (1968). "The Tragedy of the Commons." Science. no. 163. 1243-48

Schick, Allen. (1988). “A Contemporary Approach to Public Expenditure Management." Washington D.C. : The World Bank

von Hagen, Jürgen. (2006). "Budgeting Institutions for Better Fiscal Performance." in Anwar Shah (ed.), Budgeting and Budgetary Institutions. 27-51. Washington, D.C. : The World Bank OECD/DAC(2001). “Is it ODA?". Paris : OECD

OECD/DAC(2009). 'DAC Special Review of the Republic of Korea's Development Co-operation」 국제개발협력학회 홈페이지 http://www.kaidec.org

OECD/DAC 홈페이지 http://www. oecd.org/department/0,2688,en_2649_33721_1_1_1_1_1,00.html KOICA 홈페이지 http://www.koica.go.kr

$\mathrm{EDCF}$ 홈페이지 http://www.edcfkorea.go.kr 